\title{
Analisis Kesulitan Siswa dalam Menyelesaikan Soal Gerak Lurus
}

\author{
Ni Luh Yesi Andriani, Darsikin dan Amiruddin Hatibe \\ Email: Yesiniluh@gmail.com \\ Program Studi Pendidikan Fisika. FKIP, Universitas Tadulako \\ Jl. Soekarno Hatta KM.9, Kampus Bumi Tadulako TondoPalu - Sulawesi Tengah
}

\begin{abstract}
Penelitian ini bertujuan mengetahu kesulitan yang dialami, penyebab dan solusi untuk mengatasi kesulitan siswa SMA Negeri 4 Palu. Penelitian ini merupakan penelitian deskriptif-kualitatif. Subjek penelitian berjumlah 31 orang yang dipilih berdasarkan pertimbangan peneliti. Berdasarkan hasil pengolahan data hasil penelitian diperoleh kesuliatan pada tahap I sebesar 19,98\%, pada tahap II sebesar $65,78 \%$, tapah III sebesar $94,81 \%$, dan pada tahap IV sebesar $99,34 \%$. Adapun penyebabnya pada tahap I penyebab yaitu siswa tidak memahami soal dan tidak dapat menterjemahkan/mengubah soal kedalam bentuk rumus atau bentuk matematika sehingga tidak dapat menulis apa yang diketahui dan ditanyakan, (2) pada tahap II kesulitan siswa yaitu siswa tidak mengetahui rumus-rumus yang tepat digunakan untuk menghitung dan tidak dapat menerapkan konsep-konsep yang telah dipelajari,(3) pada tahp III kesulitan siswa yaitu siswa tidak dapat membentuk sistematika atau penyelesain soal dengan proses perhitungn secara benar dan bertahap. (4) pada tahap IV kesulitannya yaitu siswa tidak mengecek ulang setiap langkah penyelesaian soal dan jawaban yang diperolehnya dengan alasan kekurangan waktu dan karna tidak tahu penyelesaiannya. Solusi untuk mengatasi kesilitan siswa yaitu dengan pengajaran remedial.
\end{abstract}

Kata Kunci: Analisis, Kesulitan Siswa, Gerak Lurus, dan Deskriptif.

\section{PENDAHULUAN}

Kesulitan belajar di sebabkan oleh dua faktor yaitu faktor internal dan eksternal. Mengatasi kesulitan belajar bukanlah sesuatu yang sederhana, tidak cukup hanya dengan mengetahui taraf kecerdasan dan kemandirian siswa saja, tetapi perlu menyediakan prasarana yang memadai untuk penanganan remediasi. Penyelidikan-penyelidikan yang dapat dilakukan untuk mengetahui kesulitan belajar siswa adalah dengan mengadakan observasi, interview, tes diagnostik, dan memanfaatkan dokumentasi ${ }^{[1]}$.

Menyelesaikan masalah dalam fisika, diperlukan langkah-langkah yang sistematis agar proses penyelesaiannya mudah dan terarah. Pemecahan masalah merupakan suatu cara belajar yang dianggap efisien dalam usaha untuk mencapai tujuan pengajaran, salah satunya dengan heuristik pemecahan masalah menurut Polya. Berdasarkan pendapat ${ }^{[2]}$ "Polya menyajikan teknik pemecahan-pemecahan masalah yang tidak hanya menarik, tetapi juga dimaksudkan untuk meyakinkan konsepkonsep yang dipelajari selama belajar matematika.

Teknik/strateginya disebut Heuristik (memberi kesempatan menemukan), merupakan strategi yang membantu dalam menyelesaikan soal-soal matematika".
Dengan diketahuinya jenis kesulitan yang dihadapi siswa, maka guru dapat memberikan langkah dengan menggunakan metode pembelajaran yang dapat mengatasi kesulitan belajar siswa yang berdampak pada peningkatan hasil belajar siswa. Sangatlah penting mengetahui kesulitan siswa dalam mengerjakan soal-soal fisika agar guru dapat memberikan langkah dengan menggunakan metode pembelajaran yang dapat mengatasi kesulitan belajar siswa yang berdampak pada peningkatan hasil belajar siswa ${ }^{[3]}$.

Berdasarkan permasalahan di atas, adapun rumasan masalahnya yaitu pertama bagaimana kesulitan yang dialami siswa, kedua apa yang menyebabkan kesulitan siswa, dan ketiga yaitu bagaimana solusi untuk mengatasi kesulitan siswa tersebut. Maka penulis melakukan penelitian, dengan tujuan untuk mengetahui kesulitan yang dialami siswa, penyebab kesulitan siswa dan solusi untuk mengatasi kesulitan siswa. Fokus penelitian kali ini adalah kemampuan pemecahan masalah siswa kelas $X$ MIA 7 khususnya pada materi Gerak Lurus. Materi yang dimaksudkan adalah materi gerak lurus berubah beraturan (GLBB).

\section{METODE PENELITIAN}

Penelitian ini merupakan penelitian deskriptif dan pendekatan kualitatif dimana data diambil berdasarkan fakta-fakta yang 
diperoleh dilapangan. Subjek penelitian ini adalah siswa SMA 4 Palu pada kelas X MIA 7. Responden yang terlibat untuk memperoleh data-data diambil berdasarkan persetujuan dari siswa-siswi kelas $X$ MIA 7 dalam penelitian ini berjumlah 6 orang. Pemilihan keenam responden ini ini berdasarkan tingkat kemampuan siswa dalam memecahkan masalah yang dibagi menjadi 3 kategori yaitu 2 kategori tinggi, 2 kategori sedang dan 2 kategori rendah dalam kelompok. Pemilihan responden ini bertujuan untuk dapat memperoleh data yang dapat mencakupi keragaman kemampuan yang dimiliki siswa.

Penelitian ini dilakukan dengan meberikan tes esai pemecahan masalah yang telah divaidasi sebelumnya oleh dosen yang bertindak sebagai validator ahli. Tes esai ini terdiri dari lima soal. Penentuan skor atas jawaban subjek penelitian di lihat berdsarkan kreteria penilaian berdasarkan rubrik peneilaian secara terperinci diuraikan sebagai berikut.

I. Tahap pertama : pemahaman soal

$25=$ Memahami soal dengan baik

10 = Tidak mengindahkan syarat - syarat soal/cara interpretasi soal kurang tepat

0 =Tidak memahami soal/tidak ada jawaban

II. Kedua: Perencanaan strategi penyelesaian soal

25 = Menggunakan beberapa strategi yang benar dan mengarah pada jawaban yang benar pula

20 = Menggunakan satu strategi tertentu tetapi mengarah pada jawaban yang salah

10 = Strategi yang dijalankan kurang relevan

0 = Tidak ada rencana strategi penyelesaian

III. Pelaksanaan rencana strategi penyelesaian

$40=$ Menggunakan prosedur tertentu yang benar dan hasil benar

$30=$ Menggunakan satu prosedur tertentu yang benar tetapi salah dalam menghitung

20 = Menggunakan satu prosedur tertentu yang mengarah kepada jawaban yang benar

10 = Ada penyelesaian, tetapi prosedur tidak jelas

0 = Tidak ada penyelesaian sama sekali
IV. Pengecekan jawaban

10 =Pengecekan terhadap proses dan jawaban

5 = Pengecekan hanya pada prosesnya

5 =Pengecekan hanya pada jawaban (perhitungan)

0 = Tidak diadakan pengecekan jawaban

Setelah skor jawaban siswa diperoleh, selanjutnya dilakukan deskripsi terhadap hasil analisa data. Deskripsi dilakukan dalam tiga tahapan. Tahapan pertama adalah deskripsi mengenai besar kesulitan yang dialami siswa per butir soal. Tahapan kedua yaitu adalah deskripsi yang dilakukan berdasarkan besarnya kesulitan yang dialami siswa pada keseluruhan butir soal menurut tahapan Polya. Ketiga menghitung persentasi kesulitan siswa berdasarkan pedoman penafsiran data $^{[4]}$. Kreterian penafsiaran data yang diperlihatkan pada Tabel 2.1.

Tabel 1 Pedoman Penafsiran Data

\begin{tabular}{|l|l|}
\hline Persentase & Kriteria \\
\hline $0 \%$ & Tidak ada kesulitan \\
\hline $1 \%-25 \%$ & Sebagian kecil mengalami kesulitan \\
\hline $26 \%-49 \%$ & $\begin{array}{l}\text { Hampir setengahnya mengalami } \\
\text { kesulitan }\end{array}$ \\
\hline $50 \%$ & Setengahnya mengalami kesulitan \\
\hline $51 \%-75 \%$ & $\begin{array}{l}\text { Sebagian besar mengalami } \\
\text { kesulitan }\end{array}$ \\
\hline $76 \%-99 \%$ & $\begin{array}{l}\text { Pada umumnya mengalami } \\
\text { kesulitan }\end{array}$ \\
\hline $100 \%$ & Seluruhnya mengalami kesulitan \\
\hline
\end{tabular}

\section{Hasil Penelitian}

Setelah data diperoleh dari sampel penelitian selanjutnya dilakukan analisis terhadap data hasil penelitian tersebut, sehingga memberikan gambaran mengenai permasalahan yang diteliti, untuk itu perlu dilakukan analisis terhadap data hasil penelitian. Setelah memeriksa hasil tes pemecahan masalah terhadap 31 subjek penelitian, peneliti kemudian mengelompokan hasilnya. Adapun pengelompokannya yakni kategori tinggi ada 6 responden, kategori sedang ada 18 responden dan rendah ada 7 responden. Dari hasil yang diperoleh dipilih 2 responden kategori tinggi, 2 sedang dan 2 rendah sesui dengan persetujuan responden yang selanjutnya akan diwawancarai untuk melengkapi data yang tidak terungkap melalui tes tertulis. 
Penggolongan siswa kedalam kategori tinggi, sedang dan rendah di dapatkan dengan cara dengan terlebih dahulu menghitung jumlah skor rata-rata dan standar deviasi. Skor rata-rata yang diperoleh adalah 63,48 dan standar deviasi adalah 7,46.

Setelah peneliti mengelompokan siswa berdasarkan persentasi kesulitan pada butir soal sesui tahapan polya. Kemudian peneliti mengelompokan siswa berdasarkan persentasi jumlah siswa yang mengalami kesulitan pada setiap tahapan dari soal. Data disajikan dalam Tabel 3.1.

Tabel 2.Analisis Persentasi Pemecahan Masalah Siswa Keseluruhan

\begin{tabular}{|c|c|c|c|c|c|c|c|}
\hline \multirow{2}{*}{ Tahap Polya } & \multicolumn{5}{|c|}{ Nomor } & \multirow{2}{*}{$\begin{array}{c}\% \\
\text { kesulitan }\end{array}$} & \multirow{2}{*}{$\begin{array}{l}\text { Penapsiran } \\
\text { Data }\end{array}$} \\
\hline & 1 & 2 & 3 & 4 & 5 & & \\
\hline $\begin{array}{l}\text { Pemahaman } \\
\text { Soal }\end{array}$ & 3.23 & 22.58 & 6.45 & 16.13 & 45.16 & 18.71 & $\begin{array}{l}\text { Sebagian } \\
\text { kecil } \\
\text { mengalami } \\
\text { kesulitan }\end{array}$ \\
\hline $\begin{array}{l}\text { Rencana } \\
\text { Penyelesaian }\end{array}$ & 32.26 & 93.55 & 38.71 & 77.42 & 100 & 68.39 & $\begin{array}{l}\text { Sebagian } \\
\text { besar } \\
\text { mengalami } \\
\text { kesulitan }\end{array}$ \\
\hline $\begin{array}{l}\text { Pelaksanaan } \\
\text { Rencana }\end{array}$ & 93.55 & 100 & 90,32 & 100 & 100 & 78.71 & $\begin{array}{l}\text { Pada } \\
\text { umumnya } \\
\text { mengalami } \\
\text { kesulitan }\end{array}$ \\
\hline $\begin{array}{l}\text { Peninjauan } \\
\text { Kembali }\end{array}$ & 96.77 & 96.77 & 100 & 100 & 100 & 98.71 & $\begin{array}{l}\text { Pada } \\
\text { umumnya } \\
\text { mengalami } \\
\text { kesulitan }\end{array}$ \\
\hline
\end{tabular}

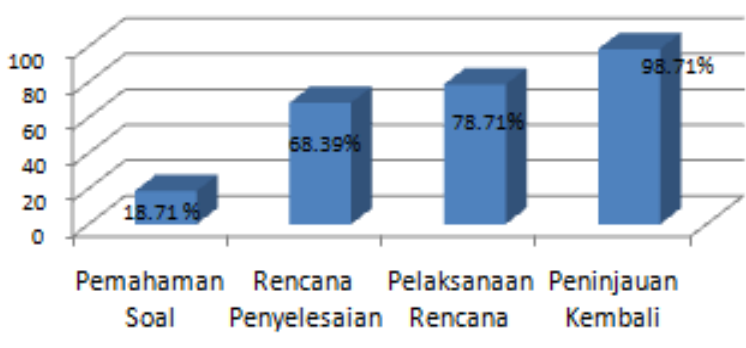

Gambar 1. Persentasi Kesullitan Siswa Berdasarkan Penapsiran Data

1. Kesulitan Setiap Tahap Pemecahan Masalah Menurut Heuristik Polya

1) Untuk Nomor 1

Soal nomor 1 membahas tentang berapa besar perlambatan yang dialami mobil apabila pada mulanya mobil bergerak dengan kelajuan $30 \mathrm{~m} / \mathrm{s}$ kemudian mengurangi kelajuannya hingga berhenti setelah 10 sekon.

Pada tahap I yaitu pemahaman soal, siswa harus dapat menuliskan apa yang diketahui dan apa yang ditanyakan dengan tepat dan sesuai. Pada tahap ini terdapai 1 dari 30 responden yang mengalami kesulitan, artinya sebagian kecil siswa tidak memahami masalah atau soal Nomor 1 dengan baik. Rata-rata persentasinya mencapai $3,22 \%$. Pada tahap II yaitu rencana penyelesaian, siswa harus dapat menuliskan definisi, rumus yang digunakan, dan rencana penyelesaian soal tes. Pada tahap ini terdapat 10 dari 31 responden yang mengalami kesulitan. Dengan rata-rata persentasi mencapai 32,25\%, artinya hampir setengahnya siswa mengalami kesulitan. Berikut kutipan jawaban responden pada Gambar 1.

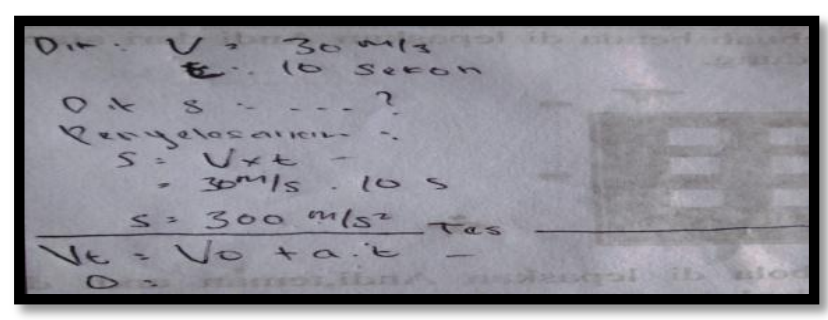

Gambar 2. kutipan jawaban responden

Adanya kesulitan pada tahap perencanaan disebabkan oleh bingungnya mereka menentukan rumus yang akan digunakan. Pada tahap III yaitu pelaksanaan rencana penyelesaian terdapat 29 dari 31 responden yang mengami kesulitan, dengan rata-rata persentasi mencapai 93,54\% . Berdasarkan penafsiran data tahap III pada umumnya mengalami kesulitan, ini disebabkan karena siswa tidak mampu menyelesaikan salah satu masalah pada soal dengan langkah-langkah penyelesaian masalah dan perhitungan yang kurang tepat dan benar, ini dapat dilihat pada kutipan jawaban gambar 3.1 tadi.

Tetapi sebagian siswa ada yang mampu menyusun rencana strategi penyelesaian masalah dan mengarah kepada salah satu jawaban yang benar, walaupun langkah - langkah penyelesaian masalah tersebut ada kekeliaruan atau kurang tepat. Sedangkan pada tahap IV yaitu peninjauan kembali adapun siswa tidak melakukan peninjauan yaitu 30 dari 31 responden. Persentasi permaslahanya mencapai $96,77 \%$, berdasarkan penafsiran data pada umumnya siswa tidak melakukan peninjauan kembali terhadap jawaban. 


\section{2) Untuk Nomor 2}

Soal nomor 2 membahas tentang berapa besar percepatan yang dialami benda melalui gambar grafik, dimana dalam gambar grafik terlihat kecepatan awal benda $4 \mathrm{~m} / \mathrm{s}$ dengan selang waktu $5 \mathrm{~s}$ kecepatan benda mencapai $12 \mathrm{~m} / \mathrm{s}$.

Dalam penelitian pada tahap I banyaknya siswa yang mengalami kesulitan yaitu 7 dari 31 responden. Nilai rata-rata responden mencapai 22,58\%, artinya sebagian kecil mengalami kesulitan. Ini menandakan bahwa siswa tersebut kurang memahami soal. Selain itu pada tahap II terdapat 29 responden yang mengalami kesulitan, dengan persentasi kesulitan mencapai 93,54\%. Ini berarti pada umumnya siswa mengalami kesulitan pada tahap ini. Kutipan jawaban dapat dilihat seperti Gambar 3:

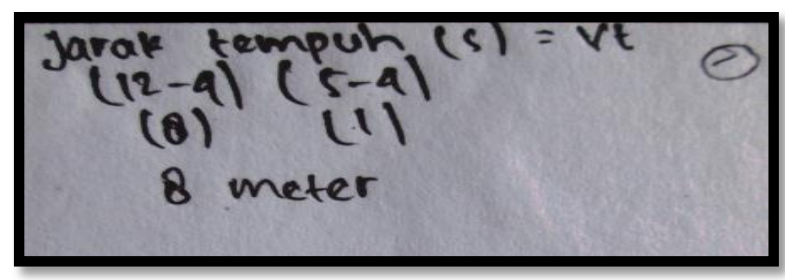

Gambar 3. kutipan jawaban responden

Siswa yang membuat kekeliruan seperti di atas, menunjukkan bahwa mereka tidak mengetahui apa sistem persamaan yang mereka susun dan tidak ada pemahaman soal. Bahkan pada tahap III rata-rata persentasi kesulitannya mencapai $100 \%$, siswa tidak mampu menyelesaikan salah satu masalah yang diajukan pada soal dengan langkah-langkah penyelesaian masalah dan perhitungan yang kurang tepat dan benar.

Sisanya, ada siswa yang menyusun rencana penyelesaian masalah dan sedikit mengarah kepada salah jawaban tetapi langkah-langkah penyelesaian masalah tersebut kurang tepat. Dan pada tahap IV persentasinya mencapai $100 \%$ artinya pada umumnya siswa tidak melakukan pengecekan jawaban.

Temuan di atas menunjukkan bahwa pemahaman siswa pada pemecahan masalah tentang gerak lurus berubah beraturan masih rendah. Salah satu penyebab dari hal ini adalah kemampuan pemahaman bahasa yang kurang. Penyebab lain adalah kurangnya minat siswa mengulang pelajaran tentang pemecahan masalah dan biasanya pada saat ujian siswa hanya bergantung dengan jawaban teman. Berkaitan dengan hal ini, pengembangan pemecahan masalah terus ditingkatkan. Salah satu cara yang dapat digunakan adalah dengan mempelajari kesulitan belajar yang dialami oleh siswa.

\section{3) Untuk Nomor 3}

Soal nomor 3 membahas tentang berapa jarak yang ia tempuh oleh pengendara sepeda apabila ia mengayun sepedanya ke puncak bukit dan ia mencapai puncak bukit dengan kelajuan $4,5 \mathrm{~m} / \mathrm{s}$. selanjutnya, ia menuruni bukit dengan percepatan $0,40 \mathrm{~m} / \mathrm{s}^{2}$ selama 12 sekon.

Pada tahap I persentasi kesulitannya mencapai 6,4516\% siswa tidak mampu melanjutkan rencana penyelesaian masalah setelah mereka menulis apa yang diketahui dan apa yang ditanyakan dari soal. Banyaknya siswa yang mengalami kesulitan yaitu 2 dari 31 siswa.

Pada tahapan II terdapat 29 dari 31 responden yang mengalami kesulitan, dengan persentasinya mencapai $38,7096 \%$ siswa yang membuat rencana penyelesaian masalah yang tidak jelas, yaitu seperti Gambar 4 :

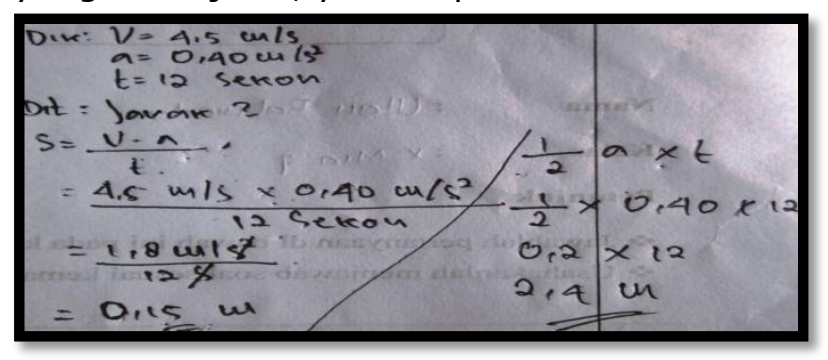

Gambar 4. kutipan jawaban responden

Siswa yang membuat kekeliruan seperti di atas, menunjukkan bahwa mereka tidak mengetahui apa sistem persamaan yang mereka susun. Bahkan pada tahap ketiga terdapat responden yang mengalami kesulitan dengan presentai mencapai 90,3225\%. Pada tahap ini siswa tidak mampu menyelesaikan salah satu masalah yang diajukan pada soal dengan langkah-langkah penyelesaian masalah dan perhitungan yang tepat dan 
benar. Sisanya, terdapat siswa yang mampu menyusun rencana penyelesaian masalah dan mengarah pada jawaban yang tepat (gambar 5):

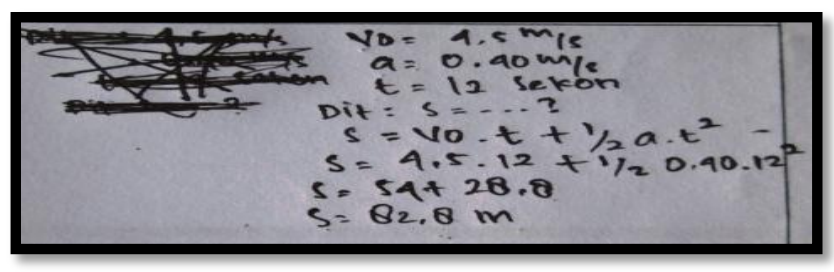

Gambar 5. kutipan jawaban responden

Dan pada tahap keempat yaitu $100 \%$ pada umumnya siswa tidak melakukan pengecekan jawaban. Salah satu penyebab dari hal ini adalah kemampuan pemahaman bahasa yang kurang. Penyebab lain adalah kurangnya minat siswa mengulang pelajaran tentang pemecahan masalah dan biasanya pada saat ujian siswa hanya bergantung dengan jawaban teman. Berkaitan dengan hal ini, pengembangan pemecahan masalah terus ditingkatkan. Salah satu cara yang dapat digunakan adalah dengan mempelajari kesulitan belajar yang dialami oleh siswa.

\section{4) Untuk Nomor 4}

Soal nomor 4 membahas tentang berapa kelajuan bola saat menyentuh tanah apabila bola dilepas dari atap sebuah gedung, dengan menghitung waktunya menggunakan stopwatch dari pertama dijatuhkan sampai ditanah yaitu $3 \mathrm{~s}$.

Pada tahap I terdapat 5 responden yang mengalami kesulitan dengan persentasi kesulitan mencapai 16,12\% siswa tidak mampu melanjutkan rencana penyelesaian masalah setelah mereka menulis apa yang diketahui dan apa yang ditanyakan dari soal. Selain itu pada tahap II terdapat 24 responden yang mengalami kesulitan dari 31 siswa dengan persentasi $77,41 \%$ siswa yang membuat rencana penyelesaian masalah yang tidak jelas, yaitu seperti gambar 7:

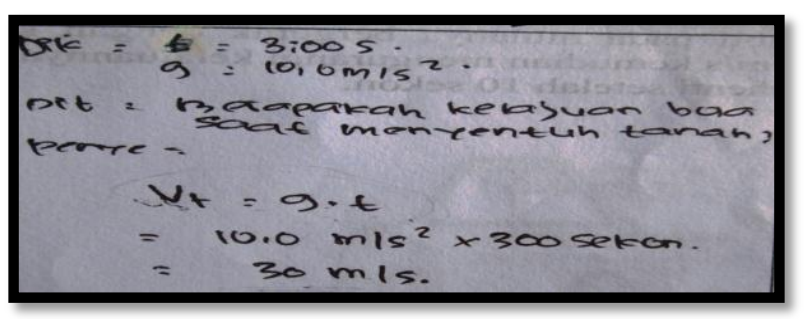

Gambar 7. kutipan jawaban responden
Siswa yang membuat kekeliruan seperti di atas, menunjukkan bahwa mereka tidak mengetahui apa sistem persamaan yang mereka susun. Bahkan pada tahap ketiga yaitu $100 \%$ siswa tidak mampu menyelesaikan salah satu masalah yang diajukan pada soal dengan langkah-langkah penyelesaian masalah dan perhitungan yang tepat dan benar. Sisanya, siswa mampu menyusun rencana penyelesaian masalah dan mengarah kepada jawaban,tetapi langkahlangkah penyelesaian masalah tersebut kurang tepat sebagai berikut (gambar 6):

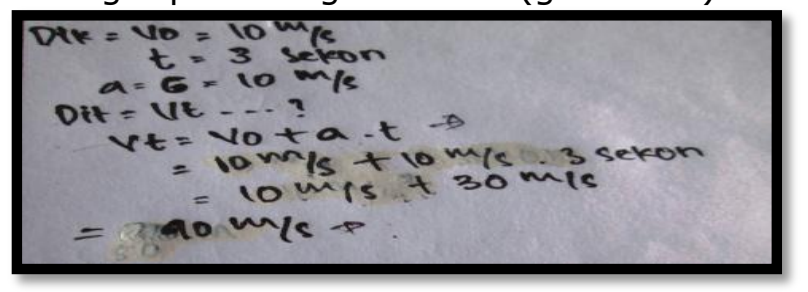

Gambar 6. kutipan jawaban responden

Dan pada tahap keempat yaitu $100 \%$ pada umumnya siswa tidak melakukan pengecekan jawaban. Temuan di atas menunjukkan bahwa pemahaman siswa pada pemecahan masalah tentang gerak lurus berubah beraturan masih rendah. Penyebab lainnya adalah kurangnya minat siswa mengulang pelajaran tentang pemecahan masalah dan biasanya pada saat ujian siswa hanya bergantung dengan jawaban teman. Berkaitan dengan hal ini, pengembangan pemecahan masalah terus ditingkatkan. Salah satu cara yang dapat digunakan adalah dengan mempelajari kesulitan belajar yang dialami oleh siswa.

\section{5) Untuk Nomor 5}

Soal nomor 5 membahas tentang berapa waktu yang diperlukan batu untuk mencapai ketinggian maksimum, apabila batu yang bermassa 200 gram dilempar lurus keatas dengan kecepatan awal $50 \mathrm{~m} / \mathrm{s}$ dengan percepatan gravitasi ditempat tersebut adalah $10 \mathrm{~m} / \mathrm{s}^{2}$ dan gesekan udara diabaikan

Pada tahap I terdapat 14 responden yang kesulitanpada tahap ini, dan persentasinya mencapai $45,1612 \%$ siswa tidak mampu melanjutkan rencana penyelesaian masalah setelah mereka menulis apa yang diketahui dan apa yang ditanyakan dari soal. Selain itu 
pada tahap II terdapat $100 \%$ siswa yang membuat rencana penyelesaian masalah yang tidak jelas, yaitu seperti gambar 8 :

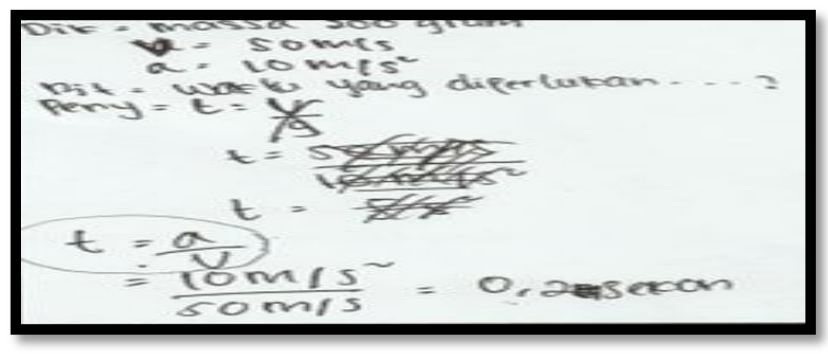

Gambar 8. kutipan jawaban responden

Siswa yang membuat kekeliruan seperti di atas, menunjukkan bahwa mereka tidak mengetahui apa sistem persamaan yang mereka susun. Bahkan pada tahap ketiga yaitu $100 \%$ siswa tidak mampu menyelesaikan salah satu masalah yang diajukan pada soal dengan kekeliaruan dalam langkah-langkah penyelesaian masalah dan perhitungan yang tepat dan benar. Sisanya, adapun siswa mampu menyusun rencana penyelesaian masalah dan mengarah kepada salah satu jawaban, tetapi langkah-langkah penyelesaian masalah tersebut kurang tepat.

Dan pada tahap keempat yaitu $100 \%$ pada umumnya siswa tidak melakukan pengecekan jawaban. Temuan di atas menunjukkan bahwa pemahaman siswa pada pemecahan masalah tentang gerak lurus berubah beraturan masih rendah. Salah satu penyebab dari hal ini adalah kemampuan pemahaman bahasa yang kurang. Penyebab lain adalah kurangnya minat siswa mengulang pelajaran tentang pemecahan masalah dan biasanya pada saat ujian siswa hanya bergantung dengan jawaban teman. Berkaitan dengan hal ini, pengembangan pemecahan masalah terus ditingkatkan. Salah satu cara yang dapat digunakan adalah dengan mempelajari kesulitan belajar yang dialami oleh siswa.

Dari kelima soal tersebut dapat dilihat hasil pemecahan masalah menurut Heuristik Polya yaitu kesulitan terbesarnya terdapat pada soal nomor 5 yaitu soal tenang gerak vertikal keatas. Terlihat pada soal ini jelas bahwa dari segi pemahaman, perencanaan, pelaksanaan dan peninjauan kembali kesulitan yang dialami siswa lebih besar dibandungkan dengan soal yang lain.

\section{Kesimpulan}

Berdasarkan hasil analisis data terhadap hasil tes soal bentuk esai pada pokok bahasan gerak lurus pada materi GLBB dapat disimpulkan bahwa penyebab kesulitan siswa SMA kelas $X$ dalam menyelesaikan soal-soal yang terkait dengan materi Gerak Lurus ditinjau dari setiap langkah penyelesaian polya yaitu pada tahap I siswa tidak memahami soal sehingga siswa yang tidak dapat menterjemahkan atau mengubah soal ke dalam bentuk matematika menyebabkan siswa tidak bisa menuliskan apa yang diketahui dan apa yang ditanyakan dalam soal. Pada tahap II siswa tidak mengetahui rumus-rumus yang tepat yang harus digunakan untuk menghitung dan siswa tidak dapat menerapkan konsep-konsep yang telah dipelajarinya. Pada tahap III siswa tidak dapat membentuk sistematika soal yang lebih baku dan tidak dapat melaksanakan proses perhitungan secara benar dan bertahap. Sedangkan pada tahap IV menurut wawancara yang dilakukan alasan siswa tidak mengecek jawaban yakni karena kehabisan/kekurangan waktu dan karena merasakan kebingungan atau siswa merasa yakin dengan jawabannya.

\section{DAFTAR PUSTAKA}

[1] Rusilowati, A. (2007). Diagnosis Kesulitan Belajar Fisika Siswa SD, SMP dan SMA dengan teknik general diagnostic dan analytic diagnostik. Prosiding Seminar

[2] Ruseffendi, E.T (1991). Pengantar kepada Membantu Guru Mengem-bangkan Kompetensinya dalam Pengajaran Matematika untuk Meningkatkan CBSA. Bandung: Tarsito

[3] Suryanti (2008) dalam Wijayanti, P.I., Mosik ,Hindarto, N., 2010, Eksplorasi Kesulitan belajar Melalui Pembelajaran Inkuiri Terbimbing 2010, IKIP PGRI Semarang.

[4] Musiri 2000. Analisis Kesulitan Siswa dalam Menyelesaikan Soal-soal Fisika pada Pokok Bahasan Rangkaian Arus Listrik Searah dengan Pendekatan Pemecahan Masalah Menurut Teori G. Polya (Skripsi). Bandung: FPMIPA UPI Bandung. 